\title{
The beauty of simplicity in science: Baltic cod stock improves rapidly in a 'cod hostile' ecosystem state
}

\author{
Massimiliano Cardinale ${ }^{1, *}$, Henrik Svedäng ${ }^{2}$ \\ ${ }^{1}$ Institute of Marine Research, National Board of Fisheries, PO Box 4, 45321 Lysekil, Sweden \\ ${ }^{2}$ Swedish Institute for the Marine Environment, PO Box 260, 40530 Göteborg, Sweden
}

\begin{abstract}
The Baltic Sea ecosystem is hypothesized to have undergone a regime shift during the last 3 decades, altering its functioning and the composition of its zooplankton and fish communities. The new stable state has been considered as 'cod hostile' due to reduced spawning success in cod, as well as increased predation on and declining food sources for cod larvae. Nonetheless, the eastern Baltic cod stock has recently recovered after more than 2 decades of low biomass and productivity. The recovery was mainly driven by a sudden reduction in fishing mortality and occurred in the absence of any exceptionally large year classes. The recovery of the cod stock during a 'cod-hostile' ecological regime indicates that fisheries are the main regulator of cod population dynamics in the Baltic Sea.
\end{abstract}

KEY WORDS: Baltic Sea ecosystem $\cdot$ Regime shift $\cdot$ Climate change $\cdot$ Gadus morhua

\section{Introduction}

Understanding the effects of fishing and climate on marine ecosystem dynamics is of central importance for the management of exploited resources (Brander 2007). Top-down and bottom-up forces usually operate in concert and their relative strength varies in response to alterations linked to external perturbations (Wilmers et al. 2006). Changes in ecosystem functioning can eventually result in alternative stable states, as shown by theoretical (Scheffer \& Carpenter 2003) and observational studies (Daskalov et al. 2007). These regime shifts are defined as transformations from one stable ecosystem configuration to a new stable state that is difficult to reverse (Scheffer \& Carpenter 2003).

Such a shift - triggered by climate-induced hydrographic changes (Möllmann et al. 2008, Österblom et al. 2010 and references therein) - has been described for the Baltic Sea ecosystem, with a reorganization due to altered trophic relationships between its major com- ponents (Möllmann et al. 2009). In the Baltic, the regime shift should also explain most of the recent dynamics of the open sea fish community (MacKenzie et al. 2007). Overfishing and eutrophication have been identified as additional drivers along with the predominant effects of altered climate forcing (Österblom et al. 2010 and references therein).

\section{Baltic regime shift}

Reorganization of the Baltic ecosystem has changed its zooplankton and fish communities (MacKenzie et al. 2007, Casini et al. 2009). Sprat Sprattus sprattus and warm water copepods Acartia spp. now dominate the open water of the Baltic Sea (MacKenzie et al. 2007), while herring Clupea harengus and the main top predator, cod Gadus morhua, have declined (ICES 2010). A large sprat stock may exert high predation pressure on cod eggs (Köster \& Möllmann 2000, Möll- 
mann et al. 2008), and together with reduced abundance of key zooplankton species for cod larvae (e.g. Pseudocalanus acuspes) and unfavorable conditions for spawning (MacKenzie et al. 2000, Köster et al. 2005), negatively affects the recruitment of cod (Möllmann et al. 2008).

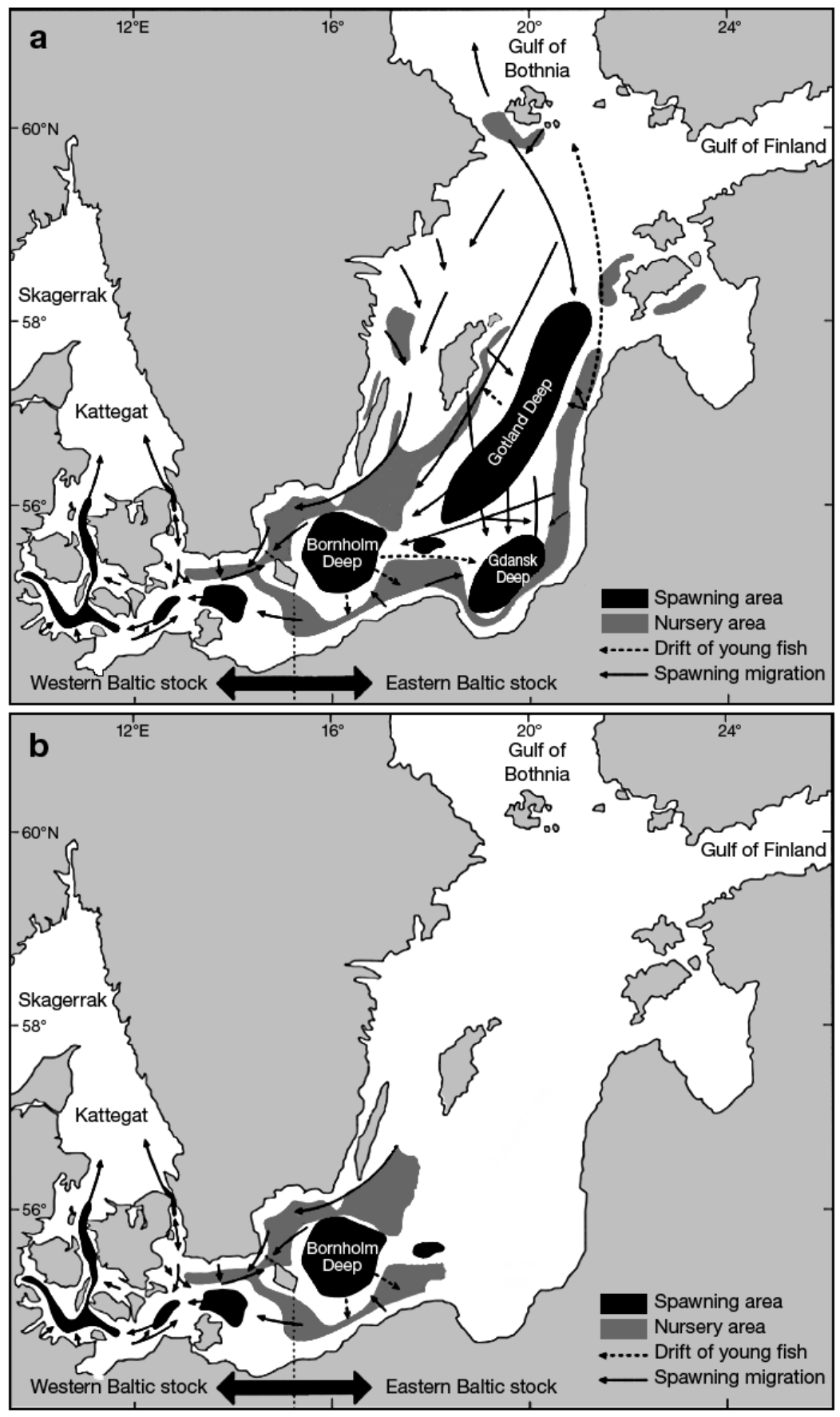

Fig. 1. Changes in the historical main spawning areas of cod Gadus morhua in the western Baltic, eastern Baltic and Danish Belt Sea (redrawn from Bagge et al. 1994). (a) Cod spawning in the Gotland Deep and Gdansk Deep as it was depicted in the 1980s; (b) cod reproduction still occurs in the Bornholm Deep, but it is negligible nowadays in the Gotland and Gdansk Deeps
This new stable state has been termed as 'cod hostile' (e.g. Möllmann et al. 2008, 2009, Lindegren et al. 2010). Such a 'new' state may have been stabilized by a negative feedback loop (i.e. hysteresis effects sensu Lindegren et al. 2010; see also Möllmann \& Köster 2002, Scheffer \& Carpenter 2003, Casini et al. 2009). In this context, an ecosystem approach involving drastic and possibly hazardous interventions (Suding et al. 2004) is considered necessary to restore the Baltic Sea ecosystem and bring it back to its 'original' configuration (ICES 2008, Diekmann \& Möllmann 2010, Österblom et al. 2010 and references therein).

However, there are other factors that may have led to a permanent change of the Baltic Sea fish community. The most important is likely to be the change of the population structure in eastern Baltic cod, a stock that has historically spawned at 3 known locations: the Bornholm Deep, the Gdansk Deep and the Gotland Deep (Aro 1989; our Fig. 1a). After the end of the 1980s, the Gdansk and Gotland Deep spawning aggregations (or subpopulations) were nearly eradicated, in particular the Gotland Deep component, where hardly any spawning activity occurs at the moment (ICES 2010). The favorable conditions for spawning and production of viable larvae have only remained in the Bornholm Deep, and even there a considerable reduction in spawning area has occurred (Hinrichsen et al. 2003).

The prime factor for this decline is probably related to climatic variation, as a decline in the frequency of oceanic water inflow from the Northeast Atlantic since the 1980s (ICES 2010) has led to a significant reduction of areas with oxygenated saline water, which is a prerequisite for successful spawning of cod (MacKenzie et al. 2000). The situation has been worsened by eutrophication and overfishing (Casini et al. 2009). From a bottom-up perspective, a decrease of the inflow of oxygenated saline water can also be referred to as a 'regime shift', as it makes the Baltic Sea less suitable for marine fishes. 


\section{Structure of the Baltic cod stock}

Does the concept of regime shifts clear, or blur, the picture? There is a need to elucidate other issues related to ecosystem changes in the Baltic Sea. To our knowledge, no investigations have ever been conducted to study the integrity of the 3 cod sub-stocks. The 'general' opinion at ICES working groups is that, when the cod stock expands, depleted aggregations will probably be refilled from neighboring ones. This idea has never been tested and, on the contrary, there is increasing evidence of rather strong natal homing behaviour in cod, as shown in adjacent stocks in the Öresund (the area between the Baltic Sea and the Kattegat), and in the Kattegat (Svedäng et al. 2007, 2010a,b). If the Baltic cod stock components are at least partly reproductively isolated from each other, the pace of recovery of the whole eastern Baltic cod stock will be hampered, even if physical conditions should improve at all spawning locations.

Nonetheless, the Baltic cod stock has recently recovered after $>2$ decades of low biomass and productivity. Between 2005 and 2009, the total biomass trebled from 120 to $350 \mathrm{kt}$, and this increase was not due to an increase in weight-at-age (ICES 2010). During the same period, fishing mortality decreased from about 1 to $<0.3$. According to the most recent assessment (ICES 2010), relatively strong year classes (of 2 year olds) were formed in 2005 and between 2007 and 2009, although the estimates for 2008 2009 are still considered as uncertain. However, recruitment in 2005 and 2007 was not high, and at the same level as in 1993 and 2000, i.e. below the overall recruitment level observed during the 1980s. We think that the recovery of the eastern Baltic cod was mainly driven by a sudden reduction in fishing mortality (because the Polish fishing fleet was paid to stay in harbor; ICES 2010).

Moreover, recent stock estimates forecast a recovery of the eastern Baltic cod stock in 2012 to levels observed just before the regime shift occurred (i.e. at the end of the 1980s) (ICES 2010), although this may not be attained due to changes in the cod population structure, such as loss of subpopulation units. Nevertheless, if the current fishing mortality $(F)$ is maintained $\left(F \leq F_{\mathrm{MSY}} F_{\mathrm{MSY}}\right.$ defined as the fishing mortality rate that provides the Maximum Sustainable Yield, MSY; Hilborn \& Walters 1992), the spawning biomass of the eastern Baltic Sea cod stock is forecast to reach levels in 2012 that are just below the maximum values in the 1920s (Eero et al. 2008) (Fig. 2). This will obviously have positive effect on the cod fisheries in the Baltic Sea in the medium term, as the Total Allowable Catch will increase (ICES 2009). The longterm level of cod yield will depend on the future average recruitment (ICES 2009). Although the sprat stock has declined in recent years, the sprat population is still at a high level of spawning biomass (ICES 2010). However, if future cod recruitment increases compared to the last $15 \mathrm{yr}$, the risk of long-term collapse of the sprat stock increases at the current estimate of $F_{\mathrm{MSY}}$ for sprat (ICES 2009).

\section{Status of the Öresund cod stock}

A similar decline has never occurred in the neighboring cod stock in the Öresund (Lindegren et al. 2010, Svedäng 2010, Svedäng et al. 2010a). The Öresund has experienced a similar hydrographically-induced regime shift, but a corresponding trophic cascade shift has not been observed (Lindegren et al. 2010). The Öresund cod stock is considered to be healthy, with a size structure that resembles that of an unexploited population.

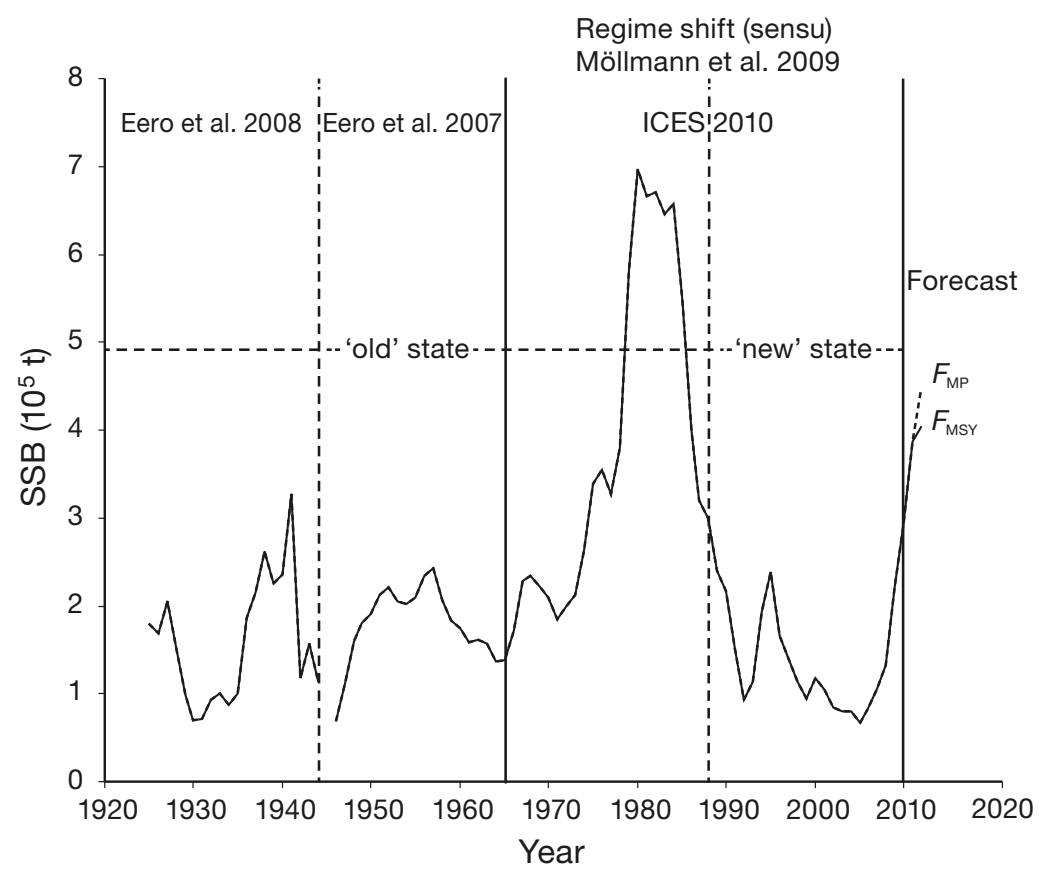

Fig. 2. Gadus morhua. Historical trend of spawning stock biomass (SSB) of eastern Baltic cod, and forecast for 2011 and 2012 at different levels of fishing mortality $(F) . F_{\mathrm{MSY}}: F$ at Maximum Sustainable Yield; $F_{\mathrm{MP}}: F$ set using the harvest control rules of the current management plan (ICES 2010). SSB estimates from 1925 to 1944 from Eero et al. (2007), from 1946 to 1965 from Eero et al. (2008), and from 1966 on from ICES (2010). A regime shift (sensu Möllmann et al. 2009) occurred in 1988, which separates the 'old' from the 'new' state of the Baltic ecosystem 
Estimates of fishing mortality in the Öresund stock are generally much lower than for the adjacent Kattegat stock (Svedäng et al. 2010a). This is likely due to the ban on trawl fishing since 1932 (Lindegren et al. 2010, Svedäng 2010) and the fact that cod in the Öresund is captured at much larger sizes, mainly by gill nets and hooks, than in the Baltic Sea. In addition, eutrophication in the Öresund has been partly halted and reversed (Lindegren et al. 2010). The healthy status of the Öresund cod stock also points to the crucial role of selectivity in the exploitation of fish populations (Froese et al. 2008), and the importance of minimizing the risk of genetic selection (Jørgensen et al. 2009) and preserving population and behavioral diversity (Svedäng et al. 2010b).

Given that the ongoing climatic stress was accompanied by higher fishing pressure, it could be argued that hysteresis effects may also have occurred in the Öresund (Lindegren et al. 2010). We think that if the environment degrades due to climatic change leading to hypoxia, and the fishing pressure increases, the fish stocks in the Öresund will be seriously affected. It is, however, a completely different matter whether such an altered ecosystem will be locked up by hysteresis effects, or not.

\section{Conclusions}

There are several lessons to be learned from the recovery of the eastern Baltic cod stock and the lack of a collapse of the Öresund cod stock, concerning the role and nature of regime shifts in the dynamics of the Baltic Sea over the last century. The substantial reduction in fishing mortality has triggered a rapid recovery of the eastern Baltic cod stock, at least in the Bornholm basin, even during a 'cod-hostile' ecological regime (e.g. Lindegren et al. 2010), and before any ecosystem management strategy was implemented. Also, the speed of the reversal is contrary to the predictions of the regime shift theory, as hysteresis did not stabilize and lock up the ecosystem in the new stable state.

Furthermore, what has been historically perceived as a 'low recruitment regime' was falsified when the stock was fished at the level of at or around $F_{\mathrm{MSY}}$. In short, single species regulation still seems to be a wellfunctioning approach in handling natural resources (see also Cardinale \& Svedäng 2008). However, this approach should include both temporal and spatial aspects of stock dynamics and fleet behavior, in order to obtain a better resolution of the relevant processes.

In summary, the fishery appears to be the main regulator of the population dynamics of cod in the Baltic, as observed for other gadoids and similar predatory fishes throughout the world's seas (Myers \& Worm
2003). Human exploitation is probably the strongest force shaping terrestrial and marine ecosystems over the last centuries (Roberts 2007, Darimont et al. 2010). Hence, by relating ecosystem perturbations to regime shift-related changes (i.e. negative trophic loops mediated by competition and predation) there is an obvious danger of letting unclear metaphors overtrump scientific endeavor for simplicity and openness to other interpretations.

\section{LITERATURE CITED}

Aro E (1989) A review of fish migration patterns in the Baltic. Rapp PV Réun Cons Int Explor Mer 190:72-96

Bagge O, Thurow F, Steffenses E, Bay J (1994) The Baltic cod. Dana 10:1-28

Brander KM (2007) Climate change and food security Special Feature: global fish production and climate change. Proc Natl Acad Sci USA 104:19709-19714

Cardinale M, Svedäng H (2008) Mismanagement of fisheries: policy or science? Fish Res 93:244-247

Casini M, Lovgren J, Hjelm J, Cardinale M, Molinero JC, Kornilovs G (2008) Multi-level trophic cascades in a heavily exploited open marine ecosystem. Proc R Soc B Biol Sci 275:1793-1801

> Casini M, Hjelm J, Molinero JC, Lovgren J and others (2009) Trophic cascades promote threshold-like shifts in pelagic marine ecosystems. Proc Natl Acad Sci USA 106: 197-202

Darimont CT, Carlson SM, Kinnison MT, Paquet PC, Reimchen TE, Wilmers CC (2009) Human predators outpace other agents of trait change in the wild. Proc Natl Acad Sci USA 106:952-954

Daskalov GM, Grishin AN, Rodionov S, Mihneva V (2007) Trophic cascades triggered by overfishing reveal possible mechanisms of ecosystem regime shifts. Proc Natl Acad Sci USA 104:10518-10523

Diekmann R, Möllmann C (eds) (2010) Integrated ecosystem assessments of seven Baltic Sea areas covering the last three decades. ICES Coop Res Rep 302. ICES, Copenhagen

Eero M, Köster FW, Plikshs M, Thurow F (2007) Eastern Baltic cod (Gadus morhua callarias) stock dynamics: extending the analytical assessment back to the mid-1940s. ICES J Mar Sci 64:1257-1271

> Eero M, Köster FW, MacKenzie BR (2008) Reconstructing historical stock development of Atlantic cod (Gadus morhua) in the eastern Baltic Sea before the beginning of intensive exploitation. Can J Fish Aquat Sci 65:2728-2741

Froese R, Stern-Pirlot A, Winker H, Gascuel D (2008) Size matters: how single-species management can contribute to ecosystem-based fisheries management. Fish Res 92: 231-241

Hilborn R, Walters CJ (1992) Quantitative fisheries stock assessment: choice, dynamics and uncertainty. Chapman \& Hall, New York, NY

Hinrichsen HH, Lehmann A, Möllmann C, Schmidt JO (2003) Dependency of larval and juvenile fish survival on retention/dispersion in food limited environments: the Baltic Sea as a case study. Fish Oceanogr 12:425-433

ICES (2008) Report of the ICES/HELCOM Working Group on Integrated Assessments of the Baltic Sea (WGIAB). ICES CM 2008/BCC:04. ICES, Copenhagen

ICES (2009) Report of the Workshop on Multi-annual Management of Pelagic Fish Stocks in the Baltic, 23-27 Febru- 
ary 2009. ICES CM 2009/ACOM:38. ICES, Copenhagen

ICES (2010) Report of the ICES Advisory Committee, ICES Advice 2010, Book 8. ICES, Copenhagen

Jørgensen C, Ernande B, Fiksen Ø (2009) Size-selective fishing gear and life history evolution in the Northeast Arctic cod. Evol Appl 2:356-370

Köster FW, Möllmann C (2000) Egg cannibalism in Baltic sprat Sprattus sprattus. Mar Ecol Prog Ser 196:269-277

Köster FW, Möllmann C, Hinrichsen HH, Wieland K and others (2005) Baltic cod recruitment-the impact of climate variability on key processes. ICES J Mar Sci 62: 1408-1425

Lindegren M, Diekmann R, Möllmann C (2010) Regime shifts, resilience and recovery of a local cod stock. Mar Ecol Prog Ser 402:239-253

MacKenzie BR, Hinrichsen HH, Plikshs M, Wieland K, Zezera AS (2000) Quantifying environmental heterogeneity: habitat size necessary for successful development of cod Gadus morhua eggs in the Baltic Sea. Mar Ecol Prog Ser 193: 143-156

MacKenzie BR, Gislason H, Möllmann C, Köster FW (2007) Impact of 21st century climate change on the Baltic Sea fish community and fisheries. Glob Change Biol 13: 1348-1367

Möllmann C, Köster FW (2002) Population dynamics of calanoid copepods and the implications of their predation by clupeid fish in the Central Baltic Sea. J Plankton Res 24: 959-977

Möllmann C, Müller-Karulis B, Kornilovs G, St. John MA (2008) Effects of climate and overfishing on zooplankton dynamics and ecosystem structure: regime shifts, trophic cascade, and feedback loops in a simple ecosystem. ICES J Mar Sci 65:302-310

Möllmann C, Diekmann R, Müller-Karulis B, Kornilovs G, Plikshs M, Axe P (2009) Reorganization of a large marine ecosystem due to atmospheric and anthropogenic pressure: a discontinuous regime shift in the Central Baltic Sea.

Editorial responsibility: Stylianos Somarakis, Heraklion, Greece
Glob Change Biol 15:1377-1393

- Myers RA, Worm B (2003) Rapid worldwide depletion of predatory fish communities. Nature 423:280-283

Österblom H, Gårdmark A, Bergström L, Müller-Karulis B and others (2010) Making the ecosystem approach operational: can regime shifts in ecological and governance systems facilitate the transition? Mar Pol 34:1290-1299

Roberts C (2007) The unnatural history of the sea: the past and the future of humanity and fisheries. Island Press, Washington, DC

> Scheffer M, Carpenter SR (2003) Catastrophic regime shifts in ecosystems: linking theory to observation. Trends Ecol Evol 18:648-656

Suding KN, Gross KL, Houseman GR (2004) Alternative states and positive feedbacks in restoration ecology. Trends Ecol Evol 19:46-53

Svedäng H (2010) Long-term impact of different fishing methods on the ecosystem in the Kattegat and Öresund. IP/B/PECH/IC/2010_24 May 2010, European Parliament, Brussels (available at: www.europarl.europa.eu/studies)

Svedäng H, Righton D, Jonsson P (2007) Migratory behaviour of Atlantic cod Gadus morhua: natal homing is the prime stock-separating mechanism. Mar Ecol Prog Ser 345:1-12

Svedäng H, Stål J, Sterner T, Cardinale M (2010a) Consequences of subpopulation structure on fisheries management: cod (Gadus morhua) in the Kattegat and Öresund (North Sea). Rev Fish Sci 18:139-150

Svedäng $H$, André C, Jonsson $P$, Elfman $M$, Limburg K (2010b) Homing behaviour and otolith chemistry suggest fine-scale sub-population structure within a genetically homogenous Atlantic cod population. Env Biol Fish 89: 383-397

Wilmers CC, Post E, Peterson RO, Vucetich JA (2006) Predator disease out-break modulates top-down, bottom-up and climatic effects on herbivore population dynamics. Ecol Lett 9:383-389

Submitted: October 28, 2010; Accepted: January 11, 2011

Proofs received from author(s): March 4, 2011 